\title{
From ménage à trois back to pas de deux? Ministerial advisers, civil servants and the contest of policy ideas
}

Richard Shaw and Chris Eichbaum

\section{(2) OpenEdition Journals}

Electronic version

URL: https://journals.openedition.org/irpp/1502

DOI: 10.4000/irpp.1502

ISSN: 2706-6274

\section{Publisher}

International Public Policy Association

\section{Printed version}

Date of publication: 15 December 2020

Number of pages: $264-280$

ISSN: 2679-3873

\section{Electronic reference}

Richard Shaw and Chris Eichbaum, "From ménage à trois back to pas de deux? Ministerial advisers, civil servants and the contest of policy ideas", International Review of Public Policy [Online], 2:3 | 2020 Online since 15 December 2020, connection on 08 September 2021. URL: http:// journals.openedition.org/irpp/1502 ; DOI: https://doi.org/10.4000/irpp.1502

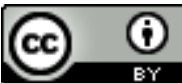

International Review of Public Policy is licensed under a Creative Commons Attribution 4.0 International. 


\section{From ménage à trois back to pas de deux? Ministerial advisers, civil servants and the contest of policy ideas}

\section{Richard Shaw}

Massey University, New Zealand

\section{Chris Eichbaum}

Victoria University of Wellington, New Zealand

\section{Abstract}

The institutionalization of the role of ministerial advisers in most parliamentary democracies has transformed what was once à pas de deux between ministers and senior civil servants into a ménage à trois. This article assesses the impact of ministerial advisers on the contest of policy ideas. It makes a theoretical case for paying closer attention to this issue than has thus far been the case, and assesses civil servants' perceptions of advisers' influence on contestability. The core conclusion, which is at variance with much of the scholarship on ministerial advisers, is that advisers pose a greater threat to policy contestability than to civil service impartiality.

\section{Keywords}

ministerial advisers, political advisers, political staff, core executive, politicization, contestability, responsive competence neutral competence 


\section{Introduction}

The institutionalization of the role of ministerial advisers in many parliamentary democracies has transformed what was once a pas de deux between ministers and senior civil servants into a ménages à trois (De Visscher \& Salomonsen, 2012). The lion's share of the electronic ink spilt examining the consequences of this development for political-administrative relations has assessed the threat that ministerial advisers allegedly pose to the impartiality of the public bureaucracy. To the best of our knowledge, however, no systematic attention has been paid to an equally salient matter: advisers' imprint on the contests that shape governments' policy agendas and their options for policy action. In the rush to determine whether ministerial advisers are chipping away at the foundations of the civil service, no-one has yet stopped to consider the bearing they are having on the contest of policy ideas.

That seems remiss, for if one accepts that advisers may have adverse impacts upon civil servants' impartiality (which is an empirical matter) there seems no reason not to believe they might have a similar influence upon contestability. Politicization and contestability are not synonyms but they are connected - one response to the question, 'Why is politicization an issue?' is, 'Because it diminishes the quality of the policy contest'. But it is one thing for ministerial advisers to politicize civil service advice and another to seek to exclude officials from the policy conversation itself. The first, if successful, will compromise the calibre of advice but the second would silence the civil service voice. Therefore, the debate regarding advisers' effects on civil service impartiality (which is well developed) must be complemented by consideration of the ramifications of their agency for the wider policy contest (about which much less is known).

In that context this article has two objectives. Our primary aim is to make a theoretical case for paying closer attention to this question: What are the consequences of ministerial advisers' agency for policy contestability? The second is to propose an answer to that query via a study of New Zealand civil servants' perceptions of ministerial advisers' influence on aspects of the policy process.

We begin by addressing both the notion of contestability and the literature on ministerial advisers, and then demonstrate how (and why) the concept of administrative politicization (Eichbaum \& Shaw, 2008; Hustedt \& Salomonsen, 2014) can shed light on the core question. Next we set out the research, which draws on survey data collected at two different periods from New Zealand public servants. Key findings are then discussed: the major conclusion, which is at variance with much of the scholarship on ministerial advisers, is that advisers pose a greater threat to policy contestability than to civil service impartiality. Finally, while the data reported here are country-specific, the material and conceptual issues we engage with are relevant in other contexts in which ministerial advisers have joined ministers and civil servants on the executive stage.

\section{Theoretical framework}

\section{The contest of policy ideas}

The etymology of the term 'contestability' in public administration is a little murky. Öhberg et al. (2017) trace it to early exchanges between proponents of élitism and pluralism, citing Bottomore's (1964) critique of pluralism and Parry's (1969) survey of classical élite theory as influences. Shepherd, however, attributes the emergence of a 'vague term' (1984, p. 572) to Baumol's (1982) attempt to establish contestability as the organizing principle of the theory of industrial organization. Baumol and others subsequently derived a series of public policy 
applications from this theoretical innovation, from whence the language of contestability appears to have entered the public administration scholarship.

Formal definitions of contestability are thin on the ground, bringing to mind the observation that 'policy is rather like the elephant - you know it when you see it but you cannot easily define it' (Hill, 1997, p. 6). This is not altogether surprising, given that the meaning of the infinitive form of the verb from which the term derives - 'to contest' - is pretty clear (although there may be less clarity regarding supplementary considerations such as 'What is being contested?' and 'To what end?'). 'Contestability' provokes reflection on the properties of the phenomenon to which it attaches (procedural openness, transparency and ease of entry to or exit from the debate, etc.). In this article the contest is one of ideas regarding the most efficacious or efficient approach to a policy challenge. Any such tussle will, of course, contain additional tacit or explicit dimensions (the relative status and professional legitimacy of contestants, questions of access to political principals, issues of control and influence, etc.), but our concern is the ideational dimension of the contest.

Normatively, contestability is assumed to be a good thing (populists aside it is difficult to imagine anyone openly calling for less contestability these days). The standard view is that it 'enhances and democratises the options available to ministers' (Walter, 2006, p. 22), which rests on the logic that provision for plural views improves the quality of policy deliberations. Broadening the advice base, increasing options for ministers and testing departments' and societal actors' positions, it is generally taken as given that a contestable process produces better outcomes. Further, decisions reached through such processes are likely to enjoy levels of legitimacy and durability that do not apply to those made on the bases of selective exclusion.

There are other ways of seeing this. Normative and positive considerations need to be separated: 'contestability' may be as much an aspirational state as an accurate description of materiality. This has less to do with its intrinsic merits than with the degree of political and administrative commitment to that aspiration. Nonetheless, it is worth noting the conditions - bounded rationality, temporal and political considerations (including the use of the term to mask a scepticism of the motives of civil servants), etc. - that may account for differences between ideal and actual states.

Such matters aside, in recent decades the institutional preconditions for greater contestability have been established through various inter-locking reform processes. Described by Pierre and Peters (2000) as 'moving up', 'moving down' and 'moving out' respectively, structural developments at the supra- and sub-national levels, as well as the re-engineering of the public sector, have spawned polycentric advisory ecosystems comprising dense networks of policy actors.

The emergence of ministerial advisers is one element of the 'hybridization' of internal policy advisory systems (Veit et al., 2017), itself an adaptive response to exogenous trends such as growing policy complexity, heightened public expectations and a voracious media cycle. These developments are shaping patterns of political demand, defined as 'the range of motivations, factors, inducements and institutional drivers which foster key decision-makers to seek out forms of policy advice' (Manwaring, 2018, p. 5; see also Craft \& Wilder, 2017). For one thing, the requirement for salient, credible and representative policy advice has grown (Veit et al., 2017); in effect, political executives require better advice on a wider slate of issues from a more catholic range of sources (Christiansen et al., 2016).

Correspondingly, changes have also taken place on the supply side. Institutional diversification and shifting demands presage a market for the provision of advice. Clearly, the equilibrium 
point at which the demand for and supply of advice intersect is not necessarily contestability within government: it might instead be the externalization, politicization or internationalization of advice (Craft \& Halligan, 2017). That said, in most jurisdictions the prerequisites for greater contestability are now designed into the institutional architecture. The virtual monopoly over supply that civil servants once exercised is long gone: where once they had a 'distinctive capacity to illuminate the dark corners of policy issues [they] now compete with a 'thousand points' of expert light' (Rourke, 1992, p. 540; cited by Öhberg et al., 2017, p. 269).

\section{Enter the adviser}

One of those sources of illumination is the ministerial adviser. Known variously in parliamentary contexts (like New Zealand) as special advisers, political advisers or exempt staff, a ministerial adviser - our preference because it clearly denotes the institutional location of the role - is defined as a 'temporary public servant appointed to provide partisan advice to a member of the political executive and who is exempt from the political impartiality requirements that apply to the standing bureaucracy' (Shaw and Eichbaum, 2018a, p. 3).

Several aspects of this definition set such advisers apart from their civil service counterparts. Ministerial advisers are usually engaged for their political skills rather than their technical expertise. While they may be employed as temporary civil servants they are generally appointed and dismissed by their ministers. The duration of an adviser's tenure is usually tied to that of the minister: the end of a ministerial career (or a breakdown in relationships) will usually also put a halt to an adviser's employment. Finally, ministerial advisers are formally exempt from any impartiality (but not ethical, honesty or integrity) requirements that apply to civil servants.

While it is often assumed that ministerial advisers are powerful players, universally able to influence policy proceedings, leverage is a function of institutional design. In the Netherlands and Denmark, for instance, the limited number of advisers relative to the size of the public bureaucracy constrains their influence (see Shaw \& Eichbaum, 2018). Context matters in other ways. Built environments, for example, can have structuring effects. Both Australian and New Zealand ministers (and their political advisers) are not co-located with their departments. This 'creates particular dynamics in relationships: [including] a clear separation between ministers and their departments, leading to problems with engagement' (Maley, 2018, p. 17). Conversely, of course, they can also make it that much easier for the ministerial adviser who is of a mind to limit civil servants' access to the minister to do just that. In short, all ministerial advisers are not equal.

The institutionalization of the role has occasioned significant scholarly activity. Given their job description and proximity to ministers, it is no surprise that the hypothesis that ministerial advisers threaten civil service impartiality has been thoroughly tested. Results have been mixed. Some find evidence in support of the proposition (Aucoin, 2012; Walter, 2006), while others argue either that there is little to be concerned about or that by attending to the political-tactical elements of advice advisers actually enable civil servants to concentrate on the provision of policy advice as per the standard Weberian prescription (Christiansen et al., 2016; LSE GV314 Group, 2012).

However, recourse to ministerial advisers can also be understood as part of the wider attempt to ensure that 'the policy choices made by the electorate [are] not defeated by an entrenched and unresponsive public bureaucracy' (Peters, 2010, p. 187). Advisers are thus positioned as a counter-bureaucracy - or, in the Belgian case, as a shadow bureaucracy (Suetens \& Walgrave, 
2001) - contesting departments' advice and serving as a portal for external interests seeking to engage in the policy process.

This reading rests on the normative assumption that the bureaucracy is disposed not to facilitate such input. That is properly an empirical question, for which there is some support (e.g. Maley, 2015), including in contexts - national and supra-national (see Rogacheva, 2019) - where political ménages à trois are long established. For instance, in highlighting the extent to which ministerial cabinets in (especially) Belgium, France and Italy function as the nodes around which external interests congregate, Suetens and Walgrave (2001) attribute the emergence of cabinets with political mistrust of officials' motives. Insofar as 'it is to ministerial cabinets that interest groups turn' (Vancoppenolle \& Brans, 2004, p. 2), that may well reflect bureaucratic obduracy - or it might simply be that societal actors know where power resides and head directly there. Either way, whatever the specifics of their institutional environments, ministerial advisers can be key brokers and, on occasion, veto players.

The scholarly pickings framed by this interpretation are, however, relatively scant, especially beyond the literature on ministerial cabinets. A sense of this is gained by comparing the results of word searches for 'contestability' and 'politicization' (and their derivates) in publications in which ministerial advisers are either the dependent or an independent variable. In a special edition of Public Administration (Hustedt et al., 2017), there are just two references to contestability in two of the eight contributions, while politicization is mentioned on 56 occasions in six articles. The same pattern applies in a recent comparative publication on advisers (Shaw \& Eichbaum, 2018b), which contains five substantive references to contestability (in two of its 12 chapters), while politicization crops up on 27 occasions in eight chapters. A reading of 50 refereed journal articles authored by established and emerging scholars is similarly instructive: excluding entries in references and running headers, the term politicization and its close relatives appear 604 times in 41 articles, while the totals for contestability are just 76 (31 of which are in Öhberg et al., 2017) and 15 respectively.

No criticism is implied in recounting these figures; they simply reflect the degree to which the investigative gaze is on one phenomenon and not the other. There are studies addressing contestability: generally they concern struggles between advisers and civil servants for access to ministers (Öhberg et al., 2017; Walter, 2006). Such contributions are, however, few and far between. Furthermore, two things are missing from the published record, such as it is. The first is a structured means of assessing advisers' impact on the policy contest, or others' perceptions thereof. Conclusions on this issue tend to be reached by way of claims or assertions rather than via heuristics; these may be perfectly plausible but a more systematic sense-making device is needed.

The second is a temporal dimension. Extant studies usually constitute snapshots and there is little or no research speaking to the extent to which ministerial advisers' agency in the policy contest changes over time either within a polity or across country contexts. This is a not a minor oversight given the plausibility of the hypothesis that time in the job matters, insofar as more experienced advisers (professional or political) might enjoy less combative relationships with their counterparts than inexperienced advisers (who may be less secure in their roles and therefore more likely to jump at shadows).

\section{Theoretical tools}

Both issues can be addressed via the concept of administrative politicization. Defined as an intervention on the part of ministerial advisers that 'offends against the principles and conventions associated with a professional and impartial civil service' (Eichbaum \& Shaw, 2008, 
p. 343), the construct has two dimensions. The first, substantive administrative politicization (SAP), captures advisers' agency intended to influence the substance of bureaucrats' advice in ways which threaten civil service neutrality. The second variant, procedural administrative politicization (PAP), describes attempts by advisers to limit officials' ability to provide free and frank advice, particularly by intervening in their relationship with the minister or in the internal workings of a department. The first has to do with the politicization of the civil service but the second speaks directly to (and constrains) contestability.

Hustedt and Salomonsen's (2017) distinction between direct and indirect political control of the bureaucracy ties the notion of administrative politicization into the wider literature on political-administrative relations. They had the difference between formal and functional understandings of politicization in mind when they drew it, but as a construct administrative politicization speaks to the sorts of 'informal mechanisms enhancing the political responsiveness of the bureaucracy' (2017, p. 395).

Öhberg et al. (2017) aside, the conceptual contrast between substance and process that is central to administrative politicization has been largely overlooked in the literature on ministerial advisers. But more needs to be squeezed out of the delineation, for it is central to the case that ministerial advisers exercise leverage over the contestability of process. Indeed, it can plausibly be argued that advisers have greater agency over the practices that comprise PAP than over those constituting SAP. Regarding the latter, the object of intervention (civil service advice) sits within the aegis of the department. A ministerial adviser can try to colour that advice with partisan considerations but the venture is subject to the veto of civil servants, whose acquiescence to or rejection of the attempt is necessarily a factor in the end result.

As to PAP, however, that object (the minister) inhabits the political rather than the administrative executive. So do ministerial advisers. This institutional proximity to their principals grants advisers more influence over the procedural aspects of the policy process than the substantive ones. Bluntly, it is easier for an adviser to obstruct officials' access to the minister or prevent their advice from reaching the minister's desk than to successfully pressure a senior civil servant into altering the substance of departmental advice.

There are, accordingly, incentives for advisers aiming to 'funnel' (Walter 2006) policy-making to engage in PAP. All else equal, attempts to constrain the provision of responsible competence will play out in the iterative processes through which governments manage the policy agenda and determine which options to pursue. Here is where the outcome of the interplay between actors is most consequential for the trajectory of policy; here is the place where the association between contestability and advisers' influence on process will be felt most keenly.

\section{The research}

\section{Design and methods}

To test this, and working from the premise that if ministerial advisers are a threat to civil servants' capacity to contribute to the policy contest, then the views of those ostensibly at risk should be sought, this research draws on data collected from New Zealand public servants through surveys conducted roughly a decade apart.

In 2005 an instrument seeking participants' perceptions of a range of ministerial advisers' interventions and actions was disseminated to public servants on the researchers' behalf by a unit within a government department. It comprised forced-choice and open-ended questions inviting respondents' views on administrative politicization, as well as a series of other mat- 
ters (e.g. the protocols governing relationships within ministerial offices and the regulation of advisers) which are not the focus of this article. Some 188 completed surveys were received (a response rate of $34.4 \%$ ).

In 2017 an abbreviated version of the survey, which retained all of the items regarding administrative politicization, was administered. This time the survey was distributed by a third party to its membership base. On this occasion 640 responses were received (a response rate of $10 \%$ ), 517 of whom were employed in a public service department or state sector entity at the time. The remainder were retired civil servants $(n=20)$, or people employed as consultants $(n=49)$ or in some other capacity $(n=54)$. Table 1 compares the composition of the two respondent groups. ${ }^{1}$

In passing we note that the first survey was administered under a social democratic administration while the second took place when a centre-right government was in office. Just under $50 \%$ of respondents to the 2017 survey are likely to have served under both (see Table 1). They will have had relationships, however, with quite different cadrés of ministerial advisers. In the absence of data from advisers we cannot yet do this, but in the future it will be important to test for a partisan effects thesis (assuming an association between ministers' political preferences and both relations with public servants and ministerial advisers' roles).

1 - The differences in these two exercises reflect challenges experienced in the second survey. They also speak to a certain sensitivity in New Zealand regarding ministerial advisers. Unlike the situation in other jurisdictions' information on the names, number, background and salary bands of ministerial advisers are not matters of public record in New Zealand, but have to be retrieved under freedom of information legislation. The 2005 research was conducted with the support of the State Services Commission, a central agency with responsibility for leadership within and the stewardship of the state sector. In 2017, however, the agency declined to support a second survey. The New Zealand Institute of Public Administration (IPANZ), the professional organization of public servants, agreed to circulate an online questionnaire to its database of members. The IPANZ database does not formally comprise a representative sample of public servants, such that the conclusions reached on the basis of the results of this research need to be treated with a measure of caution. That said, the absolute size of the respondent population $(n=640)$ is perhaps the largest group to have participated in a survey of this nature in New Zealand, and in our view permits robust descriptive statistical analysis 
Table 1: Comparing respondent groups: 2005/2017 (n; \% all respondents)

\begin{tabular}{|c|c|c|c|}
\hline \multicolumn{2}{|l|}{ Independent variables } & \multirow{2}{*}{$\begin{array}{l}\mathbf{2 0 0 5} \\
5(2.8 \%)\end{array}$} & \multirow{2}{*}{$\begin{array}{l}\mathbf{2 0 1 7} \\
9(1.8 \%)\end{array}$} \\
\hline current position & tier 1 manager (CEO) & & \\
\hline & tier 2 manager & $48(27.1 \%)$ & $30(6 \%)$ \\
\hline & tier 3 manager & $101(57.1 \%)$ & 199 (39.6\%) \\
\hline & other & $23(13 \%)$ & $264(52.6 \%)$ \\
\hline & totals & 177 & 502 \\
\hline \multirow[t]{6}{*}{ agency type } & policy & $47(26.9 \%)$ & $97(19.5 \%)$ \\
\hline & delivery & $24(13.7 \%)$ & $113(22.7 \%)$ \\
\hline & policy/delivery & $83(47.4 \%)$ & 207 (41.6\%) \\
\hline & funding/purchase & $4(2.3 \%)$ & $27(5.4 \%)$ \\
\hline & other & $17(9.7 \%)$ & $53(10.7 \%)$ \\
\hline & totals & 175 & 497 \\
\hline \multirow[t]{7}{*}{ years of service } & 21 years or longer & $62(35 \%)$ & $97(17.9 \%)$ \\
\hline & $16-20$ years & 25 (14.1\%) & $63(11.6 \%)$ \\
\hline & $11-15$ years & $33(18.6 \%)$ & 97 (17.9\%) \\
\hline & $6-10$ years & $33(18.6 \%)$ & $125(23 \%)$ \\
\hline & $1-5$ years & $22(12.4 \%)$ & $124(22.9 \%)$ \\
\hline & $<1$ year & $2(1.1 \%)$ & $36(6.6 \%)$ \\
\hline & totals & 177 & 542 \\
\hline \multirow{5}{*}{$\begin{array}{l}\text { frequency of contact } \\
\text { with ministerial } \\
\text { advisers }\end{array}$} & frequent & $41(32.1 \%)$ & $176(29.9 \%)$ \\
\hline & infrequent & $27(20.4 \%)$ & $166(28.2 \%)$ \\
\hline & minimal & $21(18.1 \%)$ & $146(24.8 \%)$ \\
\hline & none & $31(27.9 \%)$ & $101(17.1 \%)$ \\
\hline & totals & 177 & 589 \\
\hline \multirow[t]{5}{*}{ gender } & female & $85(47.5 \%)$ & $316(55.9 \%)$ \\
\hline & male & $94(52.5 \%)$ & 239 (42.3\%) \\
\hline & other* & - & $4(0.7 \%)$ \\
\hline & prefer not to respond & - & $6(1 \%)$ \\
\hline & totals & 179 & 565 \\
\hline
\end{tabular}

*: Neither 'other' nor 'prefer not to respond' were offered as alternatives in 2005. 


\section{Findings}

Table 2 compares the 2005 and 2017 responses to 10 items relating to ministerial advisers' impact upon contestability. The first three speak to the state and material nature of relationships between core executive actors, the playing out of which has consequences for the extent to which the political-administrative environment is conducive to catholicity of process. Items 4 and 5 reveal respondents' perceptions of ministerial advisers' influence over the shaping of the policy agenda; views on the degree of procedural interference from advisers which may influence the generation of comprehensive policy options are contained in items 6,7 and 8 . The final two items concern perceptions of ministerial advisers' higher level contributions to the policy process.

\section{Table 2: $\quad$ Civil servants' views on contestability (\% all respondents)}

\begin{tabular}{|c|c|c|c|c|c|c|c|c|c|c|c|c|c|}
\hline \multirow[t]{2}{*}{ Item } & \multicolumn{2}{|c|}{ SA (\%) } & \multicolumn{2}{|c|}{$\mathbf{A}(\%)$} & \multirow{2}{*}{$\begin{array}{c}\text { SA/A } \\
(\%)\end{array}$} & \multicolumn{2}{|c|}{$\mathbf{N}(\%)$} & \multirow{2}{*}{$\begin{array}{c}\mathbf{N} \\
(\%)\end{array}$} & \multicolumn{2}{|c|}{ D (\%) } & \multicolumn{2}{|c|}{ SD (\%) } & \multirow{2}{*}{$\begin{array}{c}\text { D/SD } \\
(\%)\end{array}$} \\
\hline & 2005 & 2017 & 2005 & 2017 & & 2005 & 2017 & & 2005 & 2017 & 2005 & 2017 & \\
\hline 1 relations between advisers and officials are generally positive & 3.4 & 3.3 & 63.1 & 41.5 & -21.3 & 24.6 & 42.8 & -18.2 & 8.9 & 11.2 & 0 & 1.2 & -3.5 \\
\hline 2 advisers hinder official's access to ministers & 1.7 & 4.3 & 20.7 & 27.6 & +9.5 & 39.1 & 40.7 & +1.6 & 35.8 & 25.6 & 2.8 & 1.8 & -11.2 \\
\hline $\begin{array}{l}3 \text { an adviser's presence can have an impact on a minister's } \\
\text { receptiveness to officials' advice }\end{array}$ & - & 14.7 & - & 54.3 & - & - & 25.7 & - & - & 4.8 & - & 0.5 & - \\
\hline 4 advisers have too much influence in shaping the policy agenda & 4.4 & 6.9 & 21.9 & 28 & +8.6 & 47 & 46.8 & -0.2 & 24 & 16.3 & 2.7 & 1.9 & -8.5 \\
\hline 5 advisers try to keep certain items off the policy agenda & 8.3 & 9.4 & 39.2 & 38.4 & +0.3 & 31.5 & 41 & +9.5 & 18.8 & 9.6 & 2.2 & 1.7 & -9.7 \\
\hline $\begin{array}{l}6 \text { advisers do not encourage free and frank advice on the full } \\
\text { range of policy options available to ministers }\end{array}$ & 7.8 & 12.2 & 27.9 & 30.5 & +7 & 25.1 & 36.7 & +11.6 & 33.5 & 18.0 & 5.6 & 2.6 & -18.5 \\
\hline 7 advisers prevent departmental advice from reaching ministers & 2.3 & 5.6 & 13.1 & 25.3 & +15.5 & 35.8 & 36.8 & +1 & 43.2 & 28.4 & 5.7 & 3.8 & -16.7 \\
\hline $\begin{array}{l}8 \text { public servants in } 2017 \text { are less likely to provide a minister with } \\
\text { comprehensive, free and frank advice }\end{array}$ & - & 23.7 & - & 29.6 & - & - & 21.8 & - & - & 20.5 & - & 4.5 & - \\
\hline $\begin{array}{l}9 \text { advisers facilitate interest group engagement in the policy } \\
\text { process }\end{array}$ & 3.9 & 3.1 & 38.3 & 36.7 & -2.4 & 43.9 & 40.8 & -3.1 & 12.2 & 16.5 & 1.7 & 2.9 & +5.5 \\
\hline 10 advisers make a positive contribution to the policy process & 4.9 & 7.9 & 47.3 & 36.9 & -7.4 & 37.5 & 42.9 & +5.4 & 9.2 & 11 & 1.1 & 1.2 & +1.9 \\
\hline
\end{tabular}

The first point to be made is that officials' perceptions of the state of the relationship between political and public service advisers are markedly less positive than they were in 2005 (item 1). The proportion of respondents prepared to agree that things are going swimmingly has significantly decreased, such that what emerges is an appreciably diminished sense of the health of the ties between two of the participants in the ménages à trois.

That sentiment flows over into assessments of other aspects of life in the contemporary executive triangle, including advisers' propensity to impede officials' access to ministers (item 2). Attempts to disrupt that relationship are inconsistent with contestability: successful efforts will constrain departments' capacity to contribute to policy-making but even unsuccessful attempts are likely to damage relations between colleagues. In 2017 there was decidedly more support for - and much less disagreement with - the proposition that advisers engage in this conduct than there had been a decade or so ago. In one participant's view, 'some ministerial advisers are on power trips and think their advice is the only advice that matters and is right: these advisers make life for a public servant very difficult in terms of access to ministers.' 
Item 3 casts advisers' behaviour as a potential influence on ministers' willingness to receive advice from public servants. There is much scepticism regarding advisers' conduct in this respect and it is growing. In 2005 the same question was asked but in forced choice form: 55\% of respondents to that survey indicated that they thought that advisers do shape ministers' openness to officials' advice (18\% indicated otherwise and the balance were undecided). By 2017 sentiment had hardened: nearly $70 \%$ of participants either agreed or strongly agreed with the proposition and barely $5 \%$ indicated some level of disagreement. The phrasing of the item prevents us from establishing whether that influence is for good or ill, but the pattern of responses to other items suggests that the former is probably the case.

Moreover, this effect may work subtly. Ministerial advisers often serve as political interpreters, representing ministers' preferences to officials and translating officials' responses in the other direction. In so doing they shape, even residually, the sense that one party makes of the position of the other. In this respect, even if advisers have no material influence over the gist of officials' advice, they can - through the act of interpretation - influence the way in which that advice is framed and therefore on whether it is acted on, rejected or ignored by ministers. ${ }^{2}$

In this way intra-executive interactions shape the construction of an administration's policy agenda. There is a growing sense that ministerial advisers exert too much influence over this process (item 4). It is possible that this simply signifies that advisers are prevailing in an open contest, rather than that they are successfully muffling the public service voice in the executive court. But put alongside item 5, in which a significant minority of respondents in both surveys agree that advisers actively try to keep things off the agenda, it might also suggest that the contest is skewed (and thus compromised) by the relative advantage afforded ministerial advisers by their proximity to ministers. As one official put it in the 2017 survey:

They [ministerial advisers] do interfere with the provision of free and frank advice, they overstep their boundaries, trying to tell government departments which options are or are not acceptable before a paper is submitted to ministers or Cabinet. They can interfere with the ability for officials to meet with ministers, and sway the minister's views before the minister has received advice from government departments.

Heightened concerns also emerge from responses to items concerning the ebb and flow of policy ideas. On this matter the 2017 respondents were much more wary of the consequences of ministerial advisers' actions than their equivalents had been in 2005. There was, for instance, a higher proportion of respondents concurring (and appreciably fewer disagreeing) that advisers stymie the provision of free and frank advice to ministers (item 6). Strictly speaking, the phrasing of that item rules out a categorical conclusion that ministerial advisers actively discourage contestability, but the tenor of textual data suggest that they do not welcome it. One 2017 respondent suggested that:

ministers are welcome to have ministerial advisers who play a minor role in separately providing politically oriented advice. The problem is when they act as an intermediary between the minister and public servants, who are trying to provide free, frank and politically neutral policy advice. They frequently filter what policy advice goes to the minister, actively argue against policy advice in officials' meetings and work hard to influence the topics and content of advice.

2 - We would like to thank Jostein Askim for this insight. 
Concerns were even more pronounced on the question of whether advisers obstruct the flow of public servants' advice into the inner sanctum (item 7): in 2017 nearly a third of respondents agreed or strongly agreed that they do, fully twice the levels that had applied in 2005. Perhaps the most trenchant criticism was offered by the respondent who noted that:

The minister's middle office at the moment is almost impossible to get work through, even when the minister has requested work. This blocks and subverts free and frank advice. For example, the minister's office in which I worked was heavily controlled by the minister's political adviser, who acted as a gatekeeper between the department's advice and the minister. She would, for example, refuse to allow documents containing advice with which she was unhappy to go before the minister; dictate the form in which advice could be provided (e.g. 'off-the-record' oral briefings rather than written advice); and limit the issues to be addressed in advice.

Perhaps as a partial consequence of gate-keeping conduct, there was a strong sense in 2017 that public servants are less likely to furnish free, frank and fearless advice in the current context than they might once have been (item 8). Clearly, to the extent that this is so there will be a range of factors in play, including patterns of political demand and ministerial behaviour and the erosion (or evolution) of traditional bureaucratic norms. Whatever the drivers, these data raise the possibility that in Wellington responsible competence may be eliding into responsive competence. While there is a healthy debate about whether civil servants can be responsive without also being politicized (see Mulgan, 2008; Hustedt \& Salomonsen, 2018), the distribution of respondents' sentiment on this issue points to some scepticism that the public service is presently adding its full measure to the policy contest.

A growing sense of ambivalence is also revealed in responses to items regarding advisers' contributions to the wider policy process, both with reference to bringing external voices into the policy conversation (item 9) and in overall terms (item 10). As one 2017 participant put it:

One of the risks observed with the emergence of ministerial advisers, and particularly those who have grown out of a firm relationship with a particular minister, is that they can become zealots for 'their minister's' programme and political aspirations. As such, they can become 'obstructers' to the promotion and progress of quality advice and programmes, rather than remaining the 'natural facilitators' [they would be] had they otherwise continued their political neutrality as attached public servants.

With one exception (see below) the sentiments expressed in 2017 were not significantly structured by the five independent variables deployed (respondents' rank, gender, length of service, frequency of contact with advisers and the functional focus of their employing department or agency). There was a weak association, for instance, between assessments of the state of the relationship between civil servants and advisers (item 1 ) and participants' rank (Kendall's tau-b=.053/gamma $=.089 ; \mathrm{n}=391$ ) and length of service (Kendall's tau-b=-.031/gamma=-.043; $\mathrm{n}=474$ ). The same pattern applies with regard to the other items in Table 2 . Thus, longer serving respondents were a little more likely to note the influence of advisers (item 4) than were their less experienced colleagues (Kendall's tau- $b=-.114$ /gamma $=-.157 ; n=485$ ), but there was a very weak relationship between rank and views on the matter (Kendall's tau- $b=.017$ /gamma $=.028$; $\mathrm{n}=417$ ). On other items, too, it was difficult to discern meaningful associations. Views on item 6 , for example, were not strongly shaped by seniority (Kendall's tau-b=-.075/gamma=-.097; $\mathrm{n}=502$ ), rank (Kendall's tau-b=-.041/gamma=-.064; $\mathrm{n}=417$ ) or frequency of contact (Kendall's tau- $b=.007 /$ gamma $=.010 ; n=502$ ). As to the question of the contribution advisers make to the policy process (item 10), there was effectively no relationship between respondents' views and their agencies' major functional focus (Kendall's tau-b=.001/gamma=.002; $n=417$ ). 
The exception concerns the (somewhat muted) relationship between respondents' views and frequency of contact with advisers. Those with higher rates of contact, for instance, had slightly more positive assessments on the bookend items 1 (Kendall's tau- $b=.161 /$ gamma $=.234$; $\mathrm{n}=474$ ) and 10 (Kendall's tau-b=.110/gamma=.156; $\mathrm{n}=502$ ). However, and while we cannot say conclusively whether this influence is exercised positively or negatively, they were also more likely to agree that advisers have some bearing on officials' access to ministers (item 2) (Kendall's tau- $\mathrm{b}=-.130 /$ gamma $=-.186 ; \mathrm{n}=474$ ) and on ministers' receptiveness to advice proffered by officials (item 3) (Kendall's tau-b=.132/gamma=.194; $\mathrm{n}=456$ ).

That is a slightly different picture to the one painted in 2005, when on some issues associations were more readily apparent. To take one example: in the earlier work both rank and the functional nature of respondents' agency had a clear bearing on views regarding item 7 (with less experienced officials and those in delivery agencies more likely to think poorly of advisers) (Eichbaum \& Shaw, 2008). By 2017, however, respondents' views - for good and, particularly, for ill - had become more evenly distributed across the respondent population.

To sum up: the 2005 and the 2017 data suggest that attempts by ministerial advisers to constrain, through procedural interventions, public servants' ability to contribute free, frank and comprehensive advice were considered a risk by a sizeable portion of respondents, the threat of which has appreciated over time. Westminster does not appear to be all that well in Wellington.

\section{Discussion}

The major fear concerning ministerial advisers in parliamentary democracies has been for the integrity of the standing bureaucracy (Christiansen et al., 2016; Hustedt et al., 2017; LSE GV314 Group, 2012; Öhberg et al., 2017; Walter, 2006). There is no question that this is an important issue, but in their efforts to address it scholars have neglected a second and equally significant challenge posed by advisers, which is to the rigour of the policy contest.

The first objective of this article has been to give conceptual shape to this question, including by proposing that ministerial advisers have greater agency over policy contestability than the impartiality of the civil service. That case rests on the institutional (and sometimes physical) proximity in which advisers work relative to ministers: as personal loyalists whose tenure is tied to that of a political principal, advisers are better placed to insert themselves between ministers and civil servants than to effect change in the content of departmental advice. They may attempt both, of course, but a priori the first is easier to manage than the second.

However, this claim requires some elaboration. Principally, there is a distinction between advisers' attempts to limit contestability and the material impact of those efforts, for while the institutional preconditions for such influence may exist, their success in constraining civil servants' policy input will depend on the preferences and conduct of others. After all, advisers are nested within an institutional ecosystem, such that any effects brought about by their behaviour will also be subject to the actions of the two other participants in the ménages à trois.

Bureaucrats make choices when faced with advisers behaving badly. Some may acquiesce in attempts to constrain contestability, but civil servants are not a notably supine lot and there is nothing to indicate that they routinely concede the point when confronted by such incursions. Rather, assuming that traditional conventions regarding the provision of free, frank and comprehensive advice remain in good health (and this may be moot), it is more likely that public servants will resist, rebuff or otherwise stare down attempts by ministerial advisers to cut them off at the policy pass. 
More significantly, the disposition of advisers' political principals is an important variable. It seems unlikely that a minister who values contestability will tolerate an adviser who attempts to 'funnel' a department's advice or otherwise run interference in the minister's relationship with the department. But if that assumption holds then the data set out here - which point to mounting fears that the incidence of just this sort of interference is on the rise - raise uncomfortable questions regarding ministerial dispositions in New Zealand. The possibility cannot be avoided that the concerns unearthed by this research point to growing political tolerance (if not encouragement) of the sorts of conduct analyzed in this article.

Intent cannot be attributed to ministers on the basis of other people's perceptions, of course. It may be that some ministers are complicit in advisers' endeavours; equally, what from a civil service point of view looks like an effort to constrain contestability might, from a political perspective, simply be a decision not to take officials' advice. (Equally, while filtering officials' advice can be seen as an offense against contestability, arguing against that advice or working to influence its contents might be considered consistent with the principles of contestability. One person's assault on contestability is another's exercise of that very phenomenon.) But that two thirds of respondents are of the view that advisers have an impact on ministers' receptiveness to officials' advice suggests that something is going on. One way or another, the matter needs to be better understood.

Assessing officials' perceptions of the extent and trajectory of advisers' conduct is the second core aim of the article. The evidence points to growing disquiet regarding advisers' propensity to try to constrain contestability. The point of departure is the marked deterioration in perceptions of the health of the relationship between public servants and advisers. It is conceivable, just, that contestability applies even when relations are strained. But in such circumstances the protagonists are likely to engage as combatants rather than as contestants, and the contest will probably suffer accordingly. Insofar as a functional relationship between political and professional advisers is an important (if not necessary) precondition for meaningful contestability of process, the data regarding the state of the relationship between the two sets of actors does not bode well.

Some have pointed to the potential for ministerial advisers to add value to the policy process generally, and to contestability in particular, including by attending to partisan considerations such that civil servants can concentrate on furnishing neutral competence (LSE GV314 Group, 2012). Positive sentiments regarding advisers' policy contributions could therefore be read as suggesting that the preconditions for a healthy contest are in place. Instead, there is evidence that the early enthusiasm on this count amongst New Zealand bureaucrats has cooled: that most of the early positivity has shifted into the "I'm no longer sure" category points to mounting scepticism regarding the partisans' policy input.

There is also a canary in the policy coalmine regarding another indicator of contestability. The extent to which advisers facilitate contributions from interest groups is a specific instance of a general phenomenon: the distribution of perceptions on the issue reveals something about respondents' views regarding the degree to which advisers are actively encouraging a more plural, permeable policy contest. Here, too, participants' confidence that advisers are doing this has slipped over the years.

The clearest indications that the policy contest in New Zealand is not what it might be emerge from the data concerning interventions on the part of ministerial advisers that are consistent with PAP. Part of the point of advisers is that they 'control the flow of information that reaches the minister' (Öhberg et al. 2017, p. 271). What matters is how and to what ends they exercise 
that control: managing the tide of information in order to streamline ministers' workloads is quite different to seeking to limit the expression of competing policy perspectives. It bears noting, then, that support for the proposition that ministerial advisers encourage the supply of free and frank advice - a sine qua non of contestability - is falling and that anxiety regarding advisers' exercise of their gate-keeper function to the detriment of civil servants is becoming more pronounced. It is difficult for officials to contribute meaningfully to the tussle of policy ideas if their access to ministers' offices is compromised and their papers are not being placed on ministerial desks.

\section{Conclusion: A new pas de deux?}

The data presented here reflect the views held by one element of the triangular executive and care needs to be taken not to definitively conclude on those bases that contestability in New Zealand is dead or dying. Nonetheless, for those who hold with a policy process that is inclusive, diverse and contested, those perceptions are troubling, for they point to a parlous state of affairs. In his work on contestability, Baumol (1982) argued for policy interventions that lower the barriers for aspiring competitors. Ministerial advisers, however, effectively raise the cost of entry when they seek to interfere with civil servants' engagement in the policy contest. But the price is met elsewhere: attempts to diminish the policy contribution of civil servants will detract from - and eventually impoverish - policy conversations, deliberations and decisions.

As ever, more needs to be done in order to better understand the issues in play. For one thing, the precision of the concepts used to apprehend the impact that advisers (and others) have on contestability can be improved. This article has sought to shift from assertion to heuristic clarity but there remains some way to go. Relatedly, a more rigorous test of the assertion that ministerial advisers will demonstrate a preference for PAP rather than SAP would be welcome, perhaps by systematically comparing the relative empirical incidence of the two forms of conduct.

Furthermore, our focus on public servants needs to be complemented by an equivalent concern with advisers. Critically, this would enable reflection on the earlier observation that one person's politicization is another's contestability. The point can be illustrated via reference to two competing interpretations of the threat which advisers ostensibly pose to the integrity of the policy contest. Our data suggest that for many officials that threat is material and growing. But advisers, of course, may see things differently. They might, for instance, argue there is little point in putting advice in front of the minister if it is likely to prove untenable given the ideological disposition of the government. Thus, what an official experiences as interference an adviser might regard as prudent workload management. (And, indeed, Connaughton (2018) and Maley (2011) have shown that ministers value advisers who can appropriately filter officials' advice in this way.) From this view, advisers are less an impediment to the contest of ideas than a means of enhancing the effectiveness of civil servants' input into that process.

Comparative studies of the incidence of the conduct reported here would aid understanding the extent to which the New Zealand case is indicative of a wider malaise or simply an isolated curiosity. Debates regarding the merits of contestability take place everywhere, but the configuration and institutional location of the political adviser's role is context-specific. That point applies most obviously at the level of constitutional design but is also apposite within the parliamentary world, including in the contrast between the environments of advisers who work in Napoleonic ministerial cabinets and those located either in ministerial offices (Maley, 2018) or, as in the German case, in ministries' leadership staffing units (Hustedt, 2018). 
Although the patterns within the executive triangle that feature in this article do not necessarily apply under other institutional configurations, in our view the fundamental issue - that interactions between political and professional advisers, however institutionalized, are a significant variable in the quality of the contest of policy ideas - holds beyond parliamentary systems. Of course, the requisite comparative work needs to be sensitive to different contexts. Research in the Napoleonic tradition, for instance, might be guided by two contrasting hypotheses, viz H1: The institutionalization of civil servants within ministerial cabinets facilitates PAP; and H2: Because seconded officials in cabinets remain linked (through personal and professional relations) to departments, pressures on administrative politicization are reduced ${ }^{3}$.

Those future foci aside, the depth of the concerns reported here regarding the rigour of the policy contest, and the direction in which those views are travelling, suggests that careful reflection is needed: there is little to be gained and much to be lost from a policy process that is introverted, insular and exclusive. Moreover, the consequences of gate-keeping by ministerial advisers may play out in other unwanted ways. Such conduct could, for instance, lead to responsive incompetence (Öhberg et al., 2017) within the bureaucracy, as departments selfcensor by providing only such advice as they think will be acceptable to advisers (or ministers). While that might ensure access of a sort, under such conditions the policy contest would take place in the advisory equivalent of a monoculture.

We wish to end by warning against assuming that the contents of this article are specific to New Zealand. The formal and informal institutional arrangements in place in this country are similar those of other parliamentary democracies within and beyond the Westminster community, and there is no obvious reason why the issues raised here should not also apply in other countries where ministerial advisers are now - or have long been, as is the case in Napoleonic contexts (see Brans et al., 2017; Di Mascio \& Natalini, 2013) - an institutional constant.

And if, as Peters and Pierre (2019) suggest, the advent of populist administrations in some of those contexts presages ever more challenging times for public administrators, then the question of the place of the civil service in public life becomes even more pressing. It is easier than it once was to conceive that the voice of loyalty that argues back (Heclo, 1975) may yet become a lone voice crying in the wilderness. Should that come to pass, the executive ménages à trois will have reverted to à pas de deux - but this time civil servants will be the ones on the outside looking in.

\section{Bibliography}

Aucoin, P. (2012). New Political Governance in Westminster Systems: Impartial Public Administration and Management Performance at Risk. Governance, 25(2), 177-199.

Baumol, W. (1982). Contestable Markets: An Uprising in the Theory of Industry Structure. The American Economic Review, 72(1), 1-15.

Bottomore, T. (1964). Elites and Society. London: Watts.

Brans, M. (2002). Abolishing ministerial cabinets for reinventing them. Comparative observations on political control and professional policy advice. Paper presented at the 63rd Annual Conference of the American Society for Public Administration, Phoenix.

3 - We wish to thank one of our Reviewers for drawing our attention to this matter and for suggesting the two hypotheses articulated here, neither of which we claim credit for. 
Brans, M., de Visscher, C., Gouglas, A., \& Jaspers, S. (2017). Political control and bureaucratic expertise: Policy analysis by ministerial cabinet members. In M. Brans, \& D. Aubin (Eds.), Policy analysis in Belgium (pp. 57-78). Bristol: Policy Press.

Christiansen, P, Niklasson, B., \& Öhberg, P. (2016). Does politics crowd out professional competence? The organisation of ministerial advice in Denmark and Sweden. West European Politics, 39(6), 1230-1250.

Connaughton, B. (2010). Glorified gofers, policy experts or good generalists: A classification of the roles of the Irish ministerial adviser. Irish Political Studies, 25(3), 347-369.

Craft, J., \& Halligan, J. (2017). Assessing 30 years of Westminster policy advisory system experience. Policy Science, 50(1), 47-62.

Craft, J., \& Wilder, M. (2017). Catching a Second Wave: Context and Compatibility in Advisory System Dynamics. Policy Studies Journal, 45(1), 215-39.

De Visscher, C., \& Salomonsen, H. (2012). Explaining differences in ministerial ménages à trois: multiple bargains in Belgium and Denmark. International Review of Administrative Sciences, 79(1), 71-90.

Di Mascio, F., \& Natalini, A. (2013). Analysing the role of ministerial cabinets in Italy: Legacy and temporality in the study of administrative reforms. International Review of Administrative Sciences, 79 (2), 328-346.

Eichbaum, C., \& Shaw, R. (2008). Revisiting politicization: Ministerial advisers and public servants in Westminster systems. Governance, 21(3), 337-363.

Heclo, H. (1975). OMB and the Presidency: The Problem of Neutral Competence. The Public Interest, 38(1), 80-98.

Hill, M. (1997). The Policy Process in the Modern State, London: Prentice Hall.

Hustedt, T. (2018). Germany: the smooth and silent emergence of advisory roles. In R. Shaw, \& C. Eichbaum (Eds.), Ministers, Minders and Mandarins: An International Study of Relationships at the Executive Summit of Parliamentary Democracies (pp. 72-90). London: Edward Elgar.

Hustedt, T., Kolltveit, K., \& Salomonsen, H. (2017). Ministerial Advisers in Executive Government: Out from the dark and into the limelight. Public Administration, 95(2), 299-311.

Hustedt, T., \& Salomonsen, H. (2014). Ensuring political responsiveness: Politicization mechanisms in ministerial bureaucracies. International Review of Administrative Sciences, 80(4), 746-765.

Hustedt, T., \& Salomonsen, H. (2018). From Neutral Competence to Competent Neutrality? Revisiting Neutral Competence as the Core Normative Foundation of Western Bureaucracy. In H. Byrkjeflot, \& F. Engelstad (Eds.), Bureaucracy and Society in Transition: Comparative Perspectives (pp. 69-88). Bingley, UK: Emerald Publishing Ltd..

LSE GV314 Group. (2012). New Life at the Top: Special Advisers in British Government. British Journal of Parliamentary Affairs, 65(4), 715-732.

Maley, M. (2011). Strategic links in a cut-throat world: Rethinking the role and relationships of Australian ministerial staff. Public Administration, 89(4), 1469-1488.

Maley, M. (2015). The Policy Work of Australian Political Staff. International Journal of Public Administration, 38(1), 46-55.

Maley, M. (2018). Australia: applying an institutional lens to political staff. In R. Shaw, \& C. Eichbaum (Eds.), Ministers, Minders and Mandarins: An International Study of Relationships at the Executive Summit of Parliamentary Democracies (pp. 15-33). London: Edward Elgar. 
Manwaring, R. (2018). Political demand and policy advice: a framework for analysis. Policy Studies, 40(3-4), 270-286.

Mulgan R. (2008). How much responsiveness is too much or too little? Australian Journal of Public Administration, 67(3), 345-356.

Öhberg, P., Christiansen, P., \& Niklasson, B. (2017). Administrative politicization or contestability? How ministerial advisers affect neutral competence in policy processes. Public Administration, 95(1), 269-285.

Parry, G. (1969). Political Elites. London: Allen \& Unwin.

Peters, B.G. (2010). The United States. In C. Eichbaum, \& R. Shaw (Eds.), Partisan Appointees and Public Servants: An International Analysis of the Role of the Political Adviser (pp. 180-197). Cheltenham: Edward Elgar.

Peters, B.G., \& Pierre, J. (2019) Populism and Public Administration: Confronting the Administrative State. Administration and Society, 51(10), 1521-1545.

Pierre, J., \& Peters, B.G. (2000). Governance, Politics and the State. Basingstoke, Hampshire: Macmillan Press.

Rogacheva, A. (2019). The demand for advice at the European Union level: policy advice politicization in the European Commission. Policy Studies, 40(3-4), 374-91.

Rourke, F. (1992). Responsiveness and Neutral Competence in American Bureaucracy. Public Administration Review, 52(6), 539-546.

Shaw, R., \& Eichbaum, C. (2018a). Introduction: ministers, minders and mandarins. In R. Shaw, \& C. Eichbaum (Eds.), Ministers, Minders and Mandarins: An International Study of Relationships at the Executive Summit of Parliamentary Democracies (pp. 1-14). London: Edward Elgar.

Shaw, R., \& Eichbaum, C. (2018b). (Eds.) Ministers, Minders and Mandarins: An International Study of Relationships at the Executive Summit of Parliamentary Democracies. Cheltenham: Edward Elgar.

Shepherd, W. (1984). “Contestability” vs. Competition. The American Economic Review, 74(4), 572587.

Shergold, P. (2005). “The need to wield a crowbar”: Political Will and Public Service. Dunstan Oration, Adelaide, 7 April.

Suetens, M. and Walgrave, S. (2001). Belgian Politics without Ministerial Cabinets? On the possibilities and Limitations of a New Political Culture. Acta Politica, 36(2), 180-205.

Vancoppenolle, D. and Brans, M. (2004). State-society relations in Belgian policy-making processes: Variations in governance structures and policy roles for public servants. A comparative multiple case-study. Paper presented at the 12th NISPAcee Conference, Vilnius.

Veit, S., Hustedt, T. and Bach, T. (2017). Dynamics of change in internal policy advisory systems: the hybridization of advisory capacities in Germany. Policy Sciences, 50(1), 85-103.

Walter, J. (2006). Ministers, minders and public servants: changing parameters of responsibility in Australia. Australian Journal of Public Administration, 65(3), 22-27. 